\title{
Letter
}

\section{Self-cured Flank Alopecia in a Dog}

\author{
犬の側腹部に認められた自然治癒性の脱毛 \\ Yukari Nakamura $^{1,2)}$, Yoshitsugu Inamura ${ }^{1,2)}$, Sanae Hayashiya ${ }^{1,2)}$, \\ Maiko Sekiguchi $^{3)}$, Makio Hayashiya ${ }^{4)}$, Tohru Fukase ${ }^{5)}$ \\ ${ }^{1)}$ Main Hospital and Dermatology Center of Hayashiya Animal Hospitals, ${ }^{2)}$ Division of Clinical Veterinary \\ Medicine, Hayashiya Institute of Life Sciences, ${ }^{3)}$ Department of Animal Sciences, Faculty of Life and \\ Environmental Sciences, Teikyo University of Science and Technology, ${ }^{4}$ Hayashiya Animal Hospitals, \\ ${ }^{5)}$ Hayashiya Institute of Life Sciences \\ 中村有加里 ${ }^{1,2)} *$ 稲村喜嗣 ${ }^{1,2)}$ 林屋早苗 ${ }^{1,2)}$ \\ 関口麻衣子 ${ }^{3)} \quad$ 林屋牧男 ${ }^{4)}$ 深瀬 徹 ${ }^{5)}$ \\ ${ }^{1)}$ 林屋動物診療室本院・皮膚病センター, ${ }^{2}$ 林屋生命科学研究所臨床獣医学研究部門, \\ 3) 帝京科学大学生命環境学部アニマルサイエンス学科, ${ }^{4)}$ 林屋動物診療室, ${ }^{5)}$ 林屋生命科学研究所
}

Received October 24, 2011 and accepted January 16, 2012

A castrated male Jack Russell terrier, 2 years 8 months old, was brought to the hospital at the end of March, 2010, with a chief complaint of alopecia which had been continuing for one month. The dog had developed a slight thinning of hair on both lateral sides from the chest to the femoral region, especially showing remarkable alopecia bilaterally, accompanied by macroscopic multiple pigmented macules on the flanks (Fig. 1). However, the dog exhibited no signs of itching or other symptoms such as polydipsia or polyuria. Remarkable findings were not observed in the physical examinations or hematological and blood chemical examinations, including the thyroid hormone levels. In addition, bacterial infections and ectoparasite infestations were not demonstrated by an impression smear and skin scrapings, respectively.

Histopathological examinations of biopsy samples from the skin lesions of the lateral side of both flanks revealed slight to moderate hyperkeratosis at the cornified layer of the epidermis, and pigmentation was noticed at the basal epidermal layer. The thickness of

* Correspondence to: Yukari Nakamura (Main Hospital and Dermatology Center of Hayashiya Animal Hospitals), Ogurayama 39-1205, Kohata, Uji-shi, Kyoto 611-0002, Japan

TEL +81-774-32-4450 FAX +81-774-32-0741

E-mail:honin@hysy.co.jp the epidermis was normal. Infiltration of inflammatory cells was not found in the dermis. There were no marked histopathological changes in the sebaceous glands. Slight atrophy was observed in some hair follicles with trichilemmal keratinization and no dermal papilla (Fig. 2). Ectoparasites were not detected in the follicles. Neither Gram stain-positive nor periodic acidSchiff (PAS) stain-positive organisms were detected.

The exact pathomechanisms of the alopecia in the present dog remained unidentified. A shampoo product containing phytosphingosine was applied in order to moisturize the skin which was apt to be dry due to the hair loss, although treatment with the shampoo would not be expected to be effective for hair regrowth. Hairs of the alopecia lesion started to grow gradually, 4 months after the first inspection (i.e., at the end of July) and the alopecia was fully cured by November (Fig. 3). There was no recurrence, as of late September, 2011.

There are some diseases resembling the present case, which show nonsuppurative alopecia without itching, such as hormone-related alopecia, alopecia $\mathrm{X}$ and seasonal or recurrent flank alopecia. However, hormone-related alopecia and alopecia $\mathrm{X}$ are different from the present case in some aspects of the symptoms, clinical examination findings and histopathological findings. The alopecia in the present case corresponded 


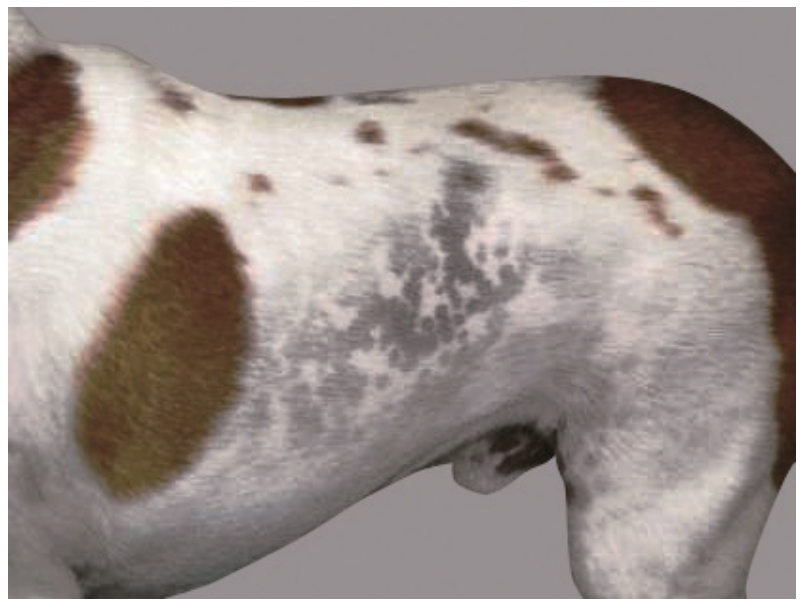

Fig. 1. Appearance of the dog showing alopecia in the flank regions.

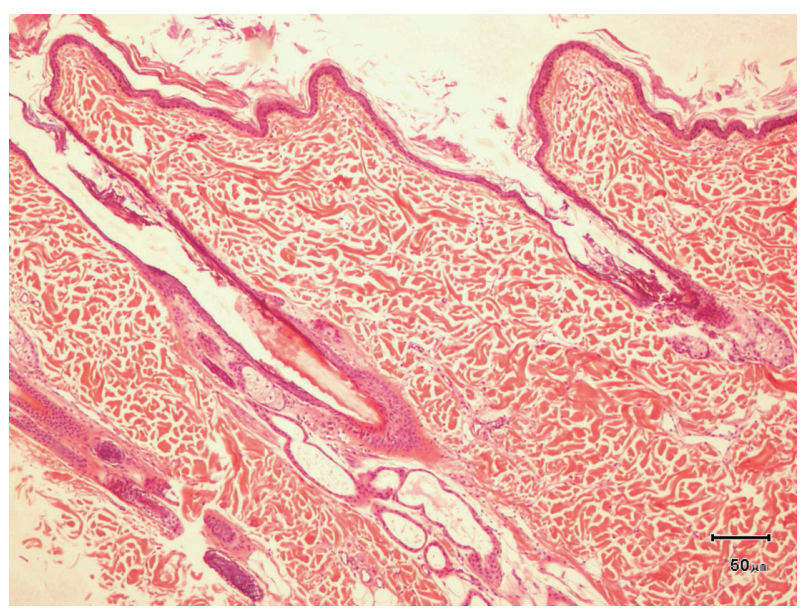

Fig. 2. Histopathological findings of the alopecia lesions (hematoxylin and eosin stain).

mainly with seasonal or recurrent alopecia, in that it occurred bilaterally in the flanks with pigmentation and also self-cured.

Seasonal or recurrent flank alopecia is well-known as hair loss occurring at the flank regions of dogs without itching, and several such cases have been reported in $\operatorname{Japan}^{1-5)}$. The alopecia in the present case occurred on the flank regions without itching, but was not typical of seasonal or recurrent flank alopecia in some respects. In typical cases, the symptoms occur repetitively in winter or early spring ${ }^{1-5)}$ and self-heal

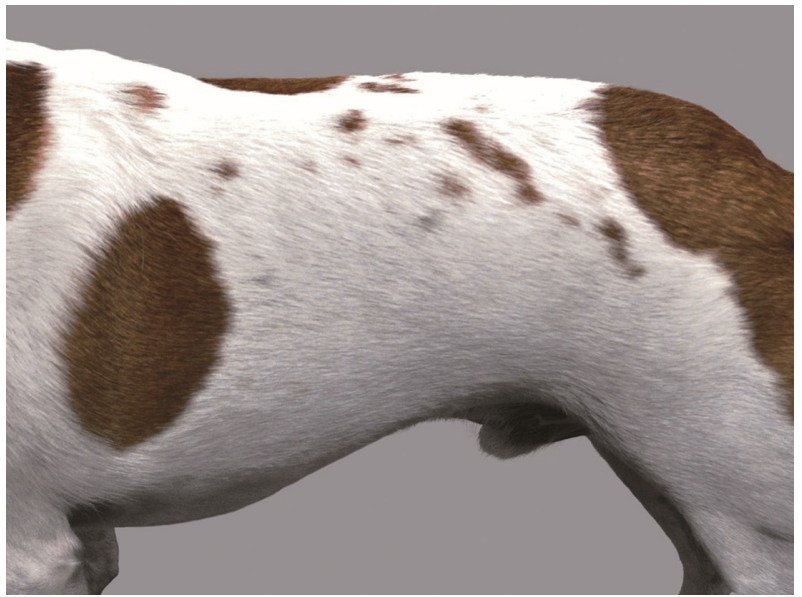

Fig. 3. Appearance of the dog after natural recovery.

by late spring or summer ${ }^{1,2,5)}$. Therefore, under the natural conditions in Japan, such cases heal as the days lengthen. The alopecia in the present case, on the other hand, continued until November, healing as the days grew shorter, and did not recur in the following year. Furthermore, the macroscopic multiple pigmented macules observed in the present case appeared different from the pigmentation which has been observed as a geographic configuration in seasonal or recurrent flank alopecia $^{1-5)}$. It was considered that the present case is not of the typical seasonal or recurrent type, but is rather a case of transitory alopecia occurring on the flank of a dog due to unknown idiopathic causes.

\section{References}

1) Akaguma, M. and Nagata, M. 2010. Jpn. J. Vet. Dermatol. 16: 219-220 (in Japanese).

2) Ando, J. and Nagata, M. 2000. Jpn. J. Vet. Dermatol. 6: 17-20 (in Japanese with English abstract).

3) Matsuda, T. 2004. Jpn. J. Vet. Dermatol. 10: 135 (in Japanese).

4) Murayama, N., Sasaki, T. and Nagata, M. 2007. Jpn. J. Vet. Dermatol. 13: 207 (in Japanese).

5) Murayama, N., Takahashi, S., Hizume, T. and Nagata, M. 2005. Jpn. J. Vet. Dermatol. 11: 1-4 (in Japanese with English abstract). 